\title{
細管式等速電気泳動法の分解能・感度に影響を及ぼす諸因子
}

\author{
治貝 基代, 秋山 純一* \\ (1977 年: 4 月 22 日受理)
}

\begin{abstract}
リーディング液への界面活性郕の添加, リーディングイオン濃度, 泳動管の温度などが, 細管式等速 電気泳動法における分解能・感度に及ぼす影響について検討した。

界面活性戍として，ポリビニルアルコール 2000 を用い，リーディソグ液への添加量 $(0.25 \sim 1.0) \%$ の間でその効果を検討した結果，(0.25〜0.5)\%の間で著しく境界面がシャープになることを認めた. リーディングイオン濃度 $(0.5 \sim 20) \mathrm{mM}$ の間では Kohlrausch の式が成り立ち，分離後の試料ゾー ソ長はリーディングイオン濃度に反比例することが分かった. リーディングイオン濃度 $10 \mathrm{mM}$ と 0.5 $\mathrm{mM}$ での最小検出量は, それぞれマレイン酸 $100 \mathrm{pmol}$ と $30 \mathrm{pmol}$ でった.

泳動管の温度が分析結果に及ぼす影響は試料により，必ずしも一様ではなかった。
\end{abstract}

1 緒言

近年，画期的な原理に基づく分離分析法として細管式 等速電気泳動法（イソタコフォレシス）が各分野で注目 されている.同法はその原理に基づく自己境界面安定化 作用により，その分離能が保証されており，分析用細管 式等速電気泳動では支持体を全く使用しないが，必要に 応じ界面活性剂などの助剂を電解液に加えることがあ る.これらの助剂は，電気浸透流などの分離に不都合な 現象を抑制し，その添加により分離・分解能が向上する ことが既に報告されている1) 3). 又, Kohlrauschの式4)5) によると, 試料イオン濃度はリーディングイオン濃度に 応じて調節され, 試料ゾーン長はリーディングィオン濃 度に反比例して長くなり，リーディングイオン濃度の希 釈により最小検出感度の向上が期待される3). 又, 泳動 管の温度に関しても若千の知見が報告されている3゙が， これらイソタコフォレシスにおける分離・分解能及び感 度に関する研究はまだ十分ではない。

著者らは，同法が今後更に各分野にわたり利用され， 各種試料を扱うに先立ち，実際の分析に利用するに際し て，より具体的な検討が必要であると考え，電位こう 配検出器及び界面活性剂としてポリビニルアルコール (PVA) 2000 を用い, そのリーディング液への添加，リ ーディングィオン濃度の希勫及び泳動管の温度などがィ ソタコフォレシスの感度・分解能に及ぼす効果について 検討したので報告する.

* (株)島津製作所科学計測事業部科学計測第 2 工場 : 尔都府京都市中京区西, 京桑原町 1
2 実 験 法

\section{$2 \cdot 1$ 装}

島津細管式等速電気泳動分析装置5)6）：IP-1B 型（島 津製作所製)

電位こう配検出器5)6)：PGD-1（同上）

\section{2 試 薬}

マレイン酸ナトリウム: 東京化成(株)製 グルタミン (Gln)，グリシン (Gly)：味の素(株)製 電解液調製用として, 以下の試薬を用いた.

塩酸, 2-アミノ-2-メチル-1,3-プロパンジオール（ア メジオール), $\beta$-アラニン, 水酸化バリウム : 和光純薬 工業(株)製の試薬特級品をそのまま用いた。

ポリビニルアルコール (PVA) 2000：和光純薬工業 （株）製を用い，規定量をあらかじめ冷水洗浄し，加熱溶 解後乃過し, Table 1 中の A-2 5 及び B-1 5 のリ一 ディング液調製に用いた.

すべての電解液調製に用いた溶媒は脱イオン水であ 万.

本実験に用いた電解液の組成を Table 1 に示す.

\section{3 分析条件}

泳動管 : 内径 $0.57 \mathrm{~mm} \times$ 長さ $20 \mathrm{~cm}$ (PTFE 製) 泳動電流 : $(5 \sim 250) \mu \mathrm{A}$

恒温乞う温度 : $(5 \sim 20)^{\circ} \mathrm{C}$ （温度効果に関与る実験以 外はいずれも $15^{\circ} \mathrm{C}$ で行った）

\section{3 実験結果及び考察}

\subsection{PVA 2000 添加の効果}

種々の界面活性剤のうち, 不純物が比較的少ないPVA 
Table 1 Electrolyte systems used in this study

\begin{tabular}{|c|c|c|c|c|c|c|c|}
\hline \multirow{2}{*}{$\begin{array}{l}\text { Electrolyte } \\
\text { systems }\end{array}$} & \multicolumn{4}{|c|}{ Leading electrolyte } & \multicolumn{3}{|c|}{ Terminal electrolyte } \\
\hline & \multicolumn{2}{|c|}{ Contents } & & $\mathrm{pH}$ & Contents & & $\mathrm{pH}$ \\
\hline A - 1 & \multicolumn{3}{|c|}{ HCl $(0.01 \mathrm{M})$, Ammediol (0.02 M) } & 9.0 & $\beta$-Alanine $(0.01 \mathrm{M})$, & $\mathrm{Ba}(\mathrm{OH})_{2}$ & 10.9 \\
\hline 2 & " , , & " & ' PVA $(0.25 \%)$ & 9.0 & " & & $"$ \\
\hline 3 & $"$ & " & ' PVA $(0.50 \%)$ & 9.0 & " & & " \\
\hline 4 & " & " & , PVA $(0.75 \%)$ & 9.0 & " & & " \\
\hline 5 & " , , & " & ' PVA $(1.00 \%)$ & 9.0 & " & & $"$ \\
\hline B - 1 & $\mathrm{HCl}(0.02 \mathrm{M})$ & Ammedioll & , PVA $(0.50 \%)$ & 9.0 & " & & $" \prime$ \\
\hline 2 & $\mathrm{HCl}(0.01 \mathrm{M})$ & " & , I & 9.0 & " & & $" 1$ \\
\hline 3 & $\mathrm{HCl}(0.005 \mathrm{M})$ & " & " & 9.0 & " & & " \\
\hline 4 & HCl $(0.001 \mathrm{M})$ & $" 1$ & " & 9.0 & " & & " \\
\hline 5 & HCl $(0.0005 \mathrm{M})$, & "I & " & 9.0 & "I & & $" \prime$ \\
\hline
\end{tabular}

2000を選び，リーディング夜への添加量が分解能に及ぼ す効果を検討した.ここで，電解液として Table 1 に示 す A-1〜5, 試料として Gln-Gly 混合液を用い, 泳動電 流を $75 \mu \mathrm{A}$ とした. Fig. 1 に PVA 無添加の場合 $\{(\mathrm{a})\}$,

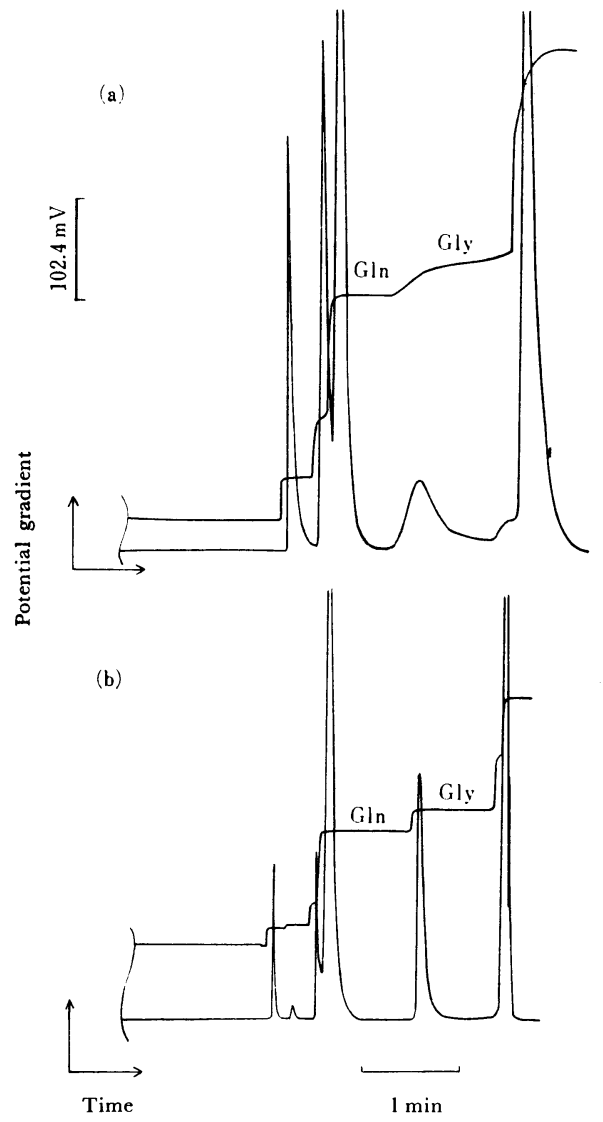

Fig. 1 Electropherograms obtained (a) without or (b) with the addition of PVA 2000 to the leading electrolyte

Electrolyte systems : (a) A-1 or (b) A-3 in Table 1 $\mathbf{0 . 5} \%$ 添加した場合 $\{(\mathrm{b})\}$ のエレクトロフェログラム を示した. Fig. 1 から, PVA の添加により, Gln-Gly 境界面が著しくシャープになっていることが分かる. 更 に, Fig. 2 に PVA の添加量（\%）と境界面のシャープ さとの関係を示した. 境界面のシャープさを表す指標と して，ここでは, 電位こう配の微分ピークの半值幅を用 いた。

これらの効果は, PVA の添加により, リーディング 液の粘性が増大し, 電気浸透流や発熱による対流, 拡散 が抑制され，ゾーン境界面が安定かつ壁面に対し，より 垂直に近い状態に保たれるためと考えられる.しかし， Fig. 2 に示すように, PVAの添加量 0.5\% 以上では, その効果の増大は認められなかった。

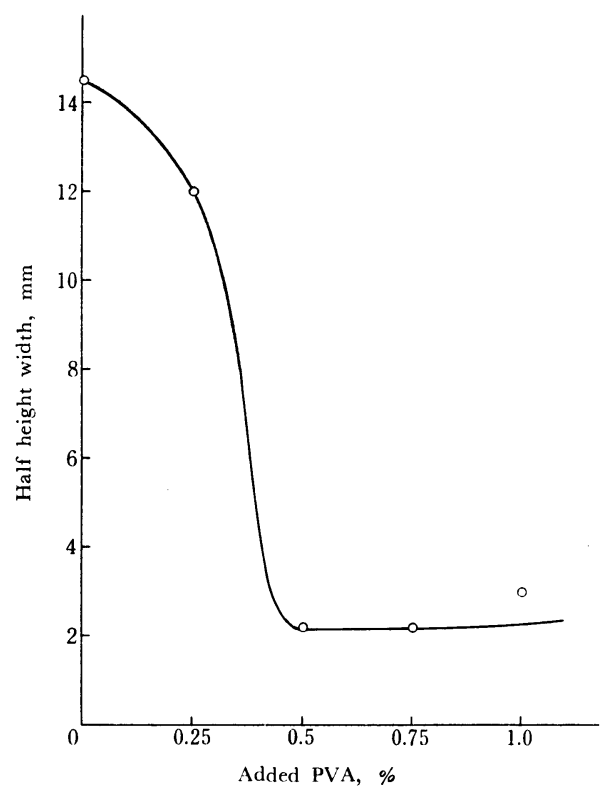

Fig. 2 Effect of added PVA to leading electrolyte on resolution Chart speed : $40 \mathrm{~mm} / \mathrm{min}$ 
この外，本実験に関して，最初 3，4 回分析を行った 後に効果が安定し, その後, PVA 未使用の電解液に交 換しても，10 回程度の分析まではその効果が残存する ことを認めた。

\section{2 リーディングイオン湿度と感度及び分解能}

試料としてマレイン酸ナトリウム， Gln-Gly 混合液 及び Table 1 に示与電解液 B-1〜5 を用いて感度及び 分解能を検討した,

Fig. 3 にリーディングィオン濃度とゾーンの実長との 関係を示す.ゾーンの実長とは定常状態に達したとき, 泳動管中で試料イオンが占める長さを意味し，イオン速 度とゾーンが電極間を通過する時間との積で表す．ただ し, イオン速度は試料注入口から検出器までの泳動管長 $(20 \mathrm{~cm})$ をその間の泳動時間で除した值とし，分離過渡 期を会む近似的な值である. 本実験では試料にマレイン 酸 $3 \mathrm{nmol}$ を用い, リーディングイオン濃度にかかわら ず試料量を一定とした。

Fig. 4 にリーディングイオン濃度 $10 \mathrm{mM}\{(\mathrm{a})\}$ と $1 \mathrm{mM}\{(\mathrm{b})\}$ におけるエレクトロフェログラムを示す.

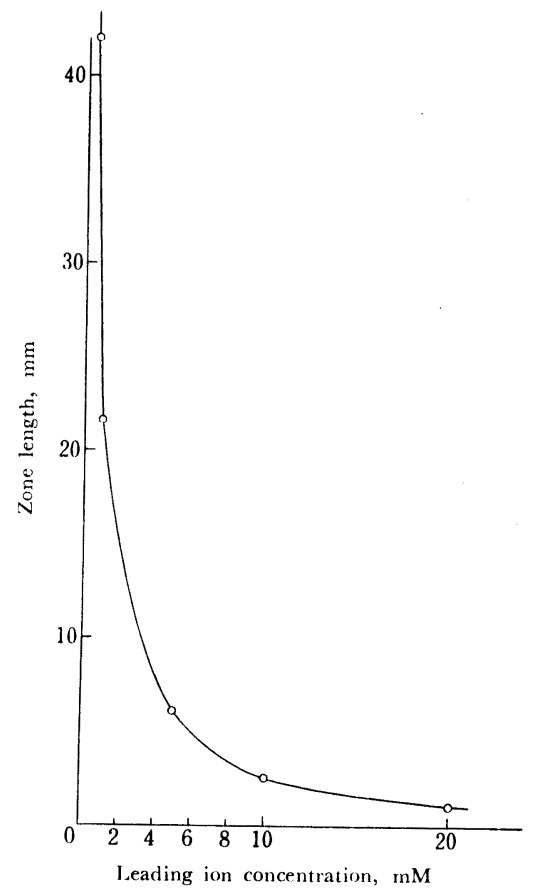

Fig. 3 Relation between leading ion concentration and zone length

Chart speed : $40 \mathrm{~mm} / \mathrm{min}$; Sample amount : $10^{-3} \mathrm{M} \times$ $3 \mu l$ maleir acid

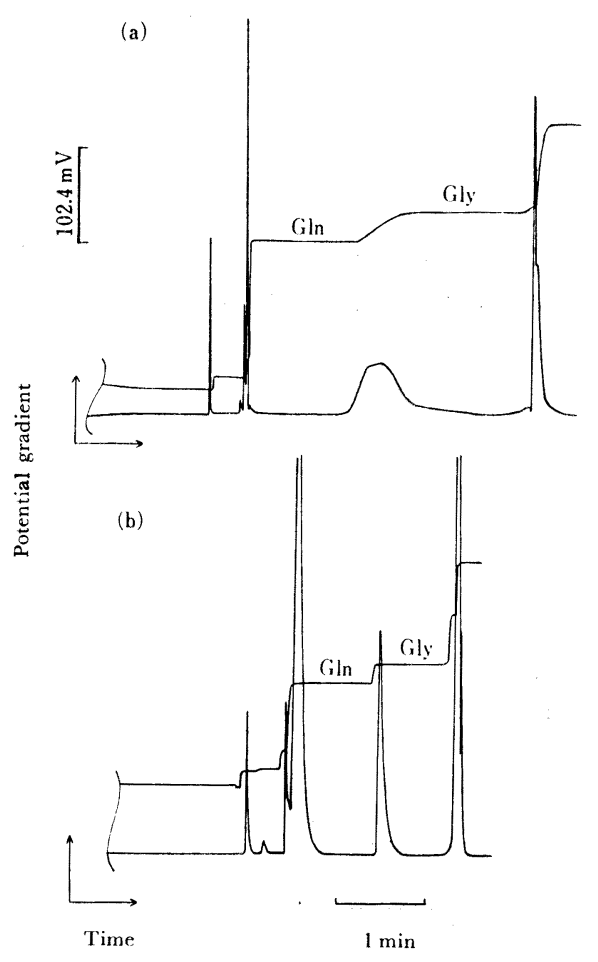

Fig. 4 Electropherograms obtained at (a) the diluted $1 \mathrm{mM}$ or (b) the common $10 \mathrm{mM}$ concentration of leading ion

Electrolyte systems : (a) B-4 or (b) B-2 in Table 1; Migration current : (a) $5 \mu \mathrm{A}$ or (b) $50 \mu \mathrm{A}$

試料には Gln-Gly 混合液を用いた。

Fig. 3 では，試料イオンゾーンの実長はリーディング イオン濃度に反比例しており, 後続するイオン濃度がリ ーディングイオン 濃度により調節され，リーディング イオン濃度とともに後続イオン濃度も低下するという Kohlrausch の式が成立していることを確認した。 しか し, 実際の最小検出量はリーディングィオン濃度 $10 \mathrm{mM}$ でマレイン酸 $100 \mathrm{pmol}, 0.5 \mathrm{mM}$ で $30 \mathrm{pmol}$ とそれほ ど感度的に向上しなかった.これは，リーディングイオ ン濃度が低くなると Fig. 4 (a) に示すように極端に境 界面のシャープさが低下し，その分離の悪さのために， 逆に検出に, より長いゾーンを要するため, 試料ゾーン が長くなる割には感度が向上しないものと考える.

\section{3 温度の影響}

電解液に Table 1 の A-3（又は B-2）を用い，(5〜 $20)^{\circ} \mathrm{C}$ の間の 4 点の温度で実験を行いその影響を調べ た. 試料に Gln-Gly 混合液を用い, 泳動電流を $75 \mu \mathrm{A}$ とした。 
Fig. 5 に $5^{\circ} \mathrm{C}$ と $20^{\circ} \mathrm{C}$ において得たエレクトロフェ ログラムを示す. 本分析条件では, Gly の電位こう配と 接近した位置にブランク (Fig. 5 中に*で示す) が検出

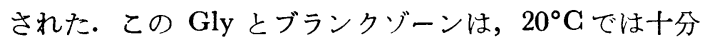

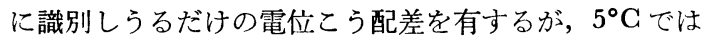
わずかに微分記緑により不純物の存在が知れるだけで， 電位こう配だけからは識別困難であった。

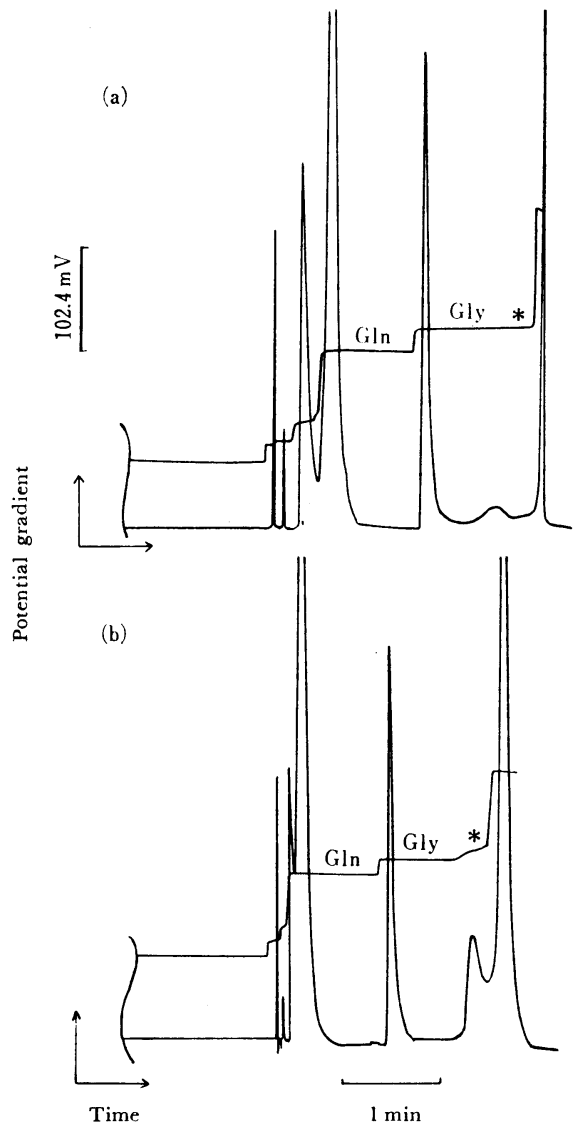

Fig. 5 Electropherograms obtained at (a) $5^{\circ} \mathrm{C}$ or (b) $20^{\circ} \mathrm{C}$

Electrolyte systems : A-3 (or B-2) in Table 1

この電位こう配差の温度に対する 変化を Fig. 6 に示 す.ここでは電位こう配差をその微分ピークの高さで表 した．Fig. 6 によると, Gln-Gly の間では温度の上昇に 伴い微分ピーク高さが低下している. すなわち， GlnGly の易動度の差が小さくなっている.これに対し Gly とブランクの間では, 逆に温度の上昇とともにその差が 広がっている，拡散定数は温度上昇とともに増大する が，その影響は同一分析において一様であると考えられ

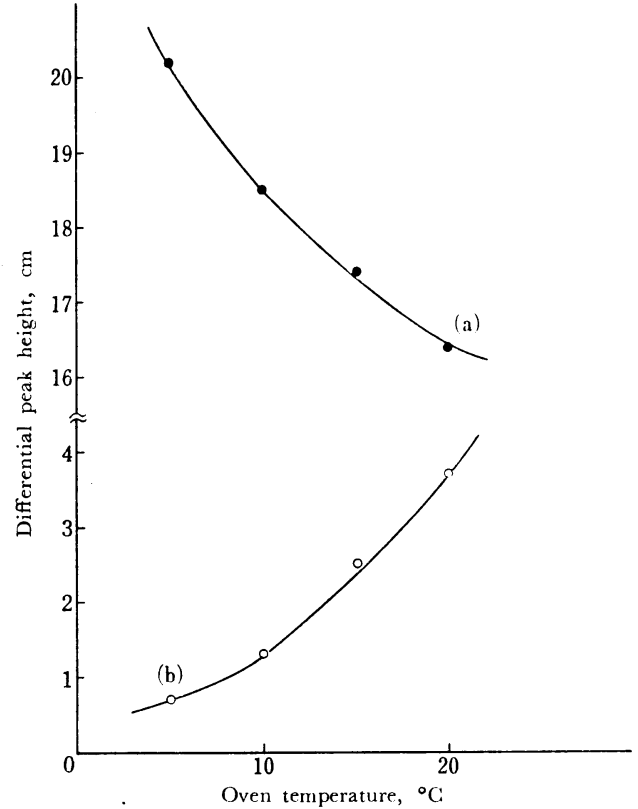

Fig. 6 Relation between the difference in potential gradient of the two components forming the consecutive zones and oven temperature

(a) Between Gln zone and Gly zone; (b) Between Gly zone and blank $\left(^{*}\right)$ zone; Differential mode : L

るので，このように同一分析において相反する結果をも たらすのは，主に各試料イオンのイオン易動度の温度に 対する増加率の違いによるものと考元られる.

\section{4 その他の因子}

泳動方向（水平，鉛直上下の 3 方向）及び泳動電流に ついては，本実験範囲では有意差を認めなかった。しか し, 前者については分析対象試料, 後者については泳動 管の冷却能力により分解能に影響它与兄ることが考兄ら れ，今後，検討の必要がある.

$$
4 \text { 絬浯 }
$$

以上リーディング液への界面活性削の添加，リーデ ィングイオン濃度, 恒温そうの温度などがイソタコフォ レシスにおける分離，分解能及び感度に及ぼす影響につ いて検討した.

界面活性剂として PVA 2000 をリーディング液に $0.5 \%$ 程度添加するとゾーン境界面が著しくシャープに なることを示した。リーディングイオン濃度としては， 分解能, 感度の点から $(5 \sim 10) \mathrm{mM}$ が適当であり, 父 ほうの発生や試料の損失も，会好目的物質に応じた滴切 
な温度を設定することがより良い分離を得るために必要 であることなどが分かった。

(1977年 4 月, 日本化学会第 36 ) 回春季年会において一部発表)

\section{交献}

1) F. M. Everaerts, Th. P. E. M. Verheggen : Science Tools, 17, 17 (1970).

2) F. M. Everaerts, P. J. Rommers : J. Chromatogr., 91, 809 (1974).

3) L. Arlinger : ibid., 91, 785 (1974).

4) H. Peeters : 生物物理化学, 20, 3 (1976).

5) 秋山純一, 水野俊英, 塩貝恭代: 島津評論, 34, 111 (1977).

6) T. Haruki, J. Akiyama : Anal. Lett., 6, 985 (1973).

$$
\grave{s}
$$

Some factors affecting resolution and detection limits of capillary tube isotachophoresis. Yasuyo Shiogai and Jun-ichi Akiyama (Analytical Instrument Plant, Shimadzu Seisakusho Ltd., 1, Nishinokyo Kuwabara-cho, Nakagyo-ku, Kyoto-shi, Kyoto)

The effects of the addition of a surfactant, polyvinyl alcohol (PVA) 2000, to the leading electrolytes, the leading ion concentrations and temperature of the capillary tube have been investigated using a potential gradient detector. Addition of PVA greatly improved the sharpness of the zone boundaries between glutamineglycine amino acids but addition of more than $0.5 \%$ of PVA gave no better results. The zone length in capillary tube after separation was inversely proportional to leading ion concentrations between 0.5 and $20 \mathrm{mM}$, but the sharpness of the zone boundaries was reduced as the leading ion concentrations were diluted, and detection limits with leading ion concentrations of 10 $\mathrm{mM}$ and $0.5 \mathrm{mM}$ were about 100 and 30 pmol for maleic acid, respectively. The effect of temperature between 5 and $20^{\circ} \mathrm{G}$ was found to be different for different samples.

(Received Apr. 22, 1977)

\section{Keywords}

Capillary tube isotachophoresis

Differential peak

Polyvinyl alcohol

Potential gradient detector

Sensitivity

Zone boundary

\title{
細管式等速電気泳動法による緑茶中のテアニン，グルタミン酸， アスパラギン酸の分析
}

\author{
篮貝 恭代，八木 孝夫，秋山 純一*
}

(1977 年5 月 18 日受理)

\begin{abstract}
細管式等速電父泳動法によるアミノ酸分析として, 緑茶中のアミノ酸を, より簡便に分離・定量する

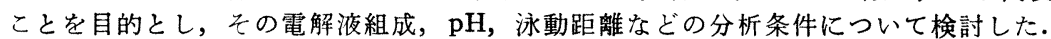

緑茶中のアミノ酸のうち，テアニン，アスパラギン酸，グルタミン酸の 3 種について検討した結果， 酸性アミノ酸は $\mathrm{pH} 3.88$ 付近の酸性条件で，テアニンは $\mathrm{pH} 7.55$ 以上のアルカリ性条件で分析する のが適当であった。茶浸出液中に目的成分と易動度が接近しているきょう雑物が存在していても，泳動 距離を長くすることで完全に分離することができ, 検量線も良好な直線性を示し, 十分に定量可能であ ることが分かった。
\end{abstract}

$$
1 \text { 緒言 }
$$

各種ア之ノ酸の定量分析には, 一般に液体クロマトグ

* (株)島津製作所科学計測事業部科学計測第二工場 : 京都府京都市中京区西ノ京桑原町 1
ラフ，ガスクロマトグラフ及び専用のア々ノ酸分析装置 などが利用されているが，これら分析法の中には，迅速 性に欠ける場合や, 誘導体化などの前処理を必要とする 場合があり, 各分野でより簡便にアるノ酸を分析するこ とが望まれている．最近になって，細管式等速電気泳動 